\title{
EQUALIZATION AND STANDARDIZATION OF MANAGEMENT OF EDUCATION IN MADRASAH
}

\author{
Sumarto \\ STAI Ma'arif Kota Jambi \\ Jl. KH. Abdurrahman Wahid, Kel. Talang Bakung, Kota Jambi \\ Email: sumarto.manajemeno@gmail.com
}

\begin{abstract}
There are different views regarding the management of education. There are those who review management in terms of functions, objects, and institutions, and others who review management as a whole. Management is a series of activities that comprises planning, organizing,mobilization and supervision in achieving predetermined objectives, and aims to explore and utilize natural resources to achieve organizational goals. Based on this, management of education is interpreted as a series or activities such as planning, organizing, motivating, controlling, and developing all efforts to regulate and utilize human resources, facilities and infrastructure to achieve goals of education. To realize good management of education requires capable and talented leaders. In this paper, study is focused on equalization and standardization of management of education in Madrasah.
\end{abstract}

Abstrak. Para ahli berbeda pendapat tentang manajemen pendidikan. Ada yang meninjau pengelolaan dari segi fungsi, benda, kelembagaan dan yang meninjau pengelolaan sebagai suatu kesatuan. Manajemen adalah suatu rangkaian kegiatan yang berintikan perencanaan, pengorganisasian pengerakan dan pengawasan dalam mencapai tujuan yang telah ditetapkan sebelumnya. Dengan demikian, manajemen pendidikan dapat diartikan sebagai serangkaian atau beberapa kegiatan merencanakan (planning), mengorganisasikan (organizing), memotivasi (motivation), mengendalikan (controling) dan mengembangkan (development) segala upaya di dalam mengatur dan mendayagunakan sumber manusia, sarana dan prasarana untuk mencapai tujuan pendidikan. Tulisan ini lebih konsentrasi pada pemerataan dan standarisasi pengelolaan pendidikan di Madrasah.

Keywords: equalization, standardization, management of education

DOI: http://dx.doi.org/10.24239/jsi.v14i1.450.117-139 


\section{Introduction}

Management is a series of activities that comprise planning, organization, mobilization and supervision in achieving predetermined objectives. ${ }^{1}$ Education is a conscious and wellplanned effort to create the atmosphere and process of learning so that students actively develop their potential to have spiritual power, self-control, personality, intelligence, noble character, and skills. ${ }^{2}$

Education is a major force in community to balance the development of science and technology. This mobilizes intellectuals to respond simultaneously to the development and system of education and its related elements which tend positively to realize the success of education. ${ }^{3}$

National Education System Number 20 Year 2003 and Badan Standar Nasional Pendidikan (Agency for Standar National Education) stated that national education aims to develop the potential of learners to become human beings who have faith, pious, noble, healthy, knowledgeable, creative, independent, and become citizens who are democratic and responsible. ${ }^{4}$

The purpose of education includes three aspects: cognitive, affective and psychomotor. Until now, the most influential factor

${ }^{1}$ H.A.R. Tilaar, Kekuasaan dan Pendidikan: Manajemen Pendidikan Nasional dalam Pusaran Kekuasaan (Jakarta: PT Rineka Cipta, 2009). 41.

${ }^{2}$ Law on National Education System No. 20 Year 2003. In Chapter II Article 3 reads: National Education serves to develop ability and form the nation's character and dignified civilization in order to educate nation's life, and aims to improve student's potential in order to be a man who has faith in God and piety, good character, good health, knowledge, creativity, independence, and to be democratic and responsible citizen. See Republik Indonesia, Undang-Undang Nomor 20 Tahun 2003 Tentang Sistem Pendidikan Nasional, 4th ed. (Jakarta: Sinar Grafika, 2011).

${ }^{3}$ Ahmad Barizi and Muhammad Idris, Menjadi Guru Unggul (Yogyakarta: Ar-Ruzz Media, 2009). 129.

${ }^{4}$ Republik Indonesia, Undang-Undang Nomor 20 Tahun 2003 Tentang Sistem Pendidikan Nasional and National Education Standards Agency (BSNP). 
on the learning outcomes is cognitive that include perception, memory and thinking, while affective and psychomotor aspects are complementary to determine the success of student's learning in school. ${ }^{5}$

According to UNESCO, present education aims to prepare people. The concept of education system may change according to the development of society and the transfer of cultural values. This concept today cannot be separated from education that must be in accordance with the demands of educational needs either in the past, present or future.

From the definitions stated above, in principle it has in common; that is, a conscious, planned, systematic, continous effort. Management of madrasah education is defined as a series of efforts undertaken by a group of people to perform a series of work in achieving certain goals.

The word "management" comes from the ancient French ménagement, which means the art of implementing and managing (including management of education). Management does not yet have a established and universally accepteddefinition. Mary Parker Follet, for example, defines management as the art of completing work through others. This definition means that a manager is in charge of organizing and directing others to achieve organizational goals.

Ricky W. Griffin defines management as a process of planning, organizing, and controlling resources to achieve goals effectively and efficiently. Effective means that goals can be achieved in accordance with planning, while efficient means that the tasks are implemented correctly, organized and timely.

As explained before that one of the most important aspects of management of education is organizing. Good organization 110-111.

${ }^{5}$ Abu Ahmadi, Startegi Belajar Mengajar (Bandung: Pustaka Setia, 2005). 
should have a good ethical basis. Good organizing will create a good organization, either in its structure, human resources, or other aspects. The organization itself is defined as a collection of people with a system of cooperation to achieve common goals. ${ }^{6}$

According to Handoko, organizing includes 1) determining resources and activities needed to achieve organizational goals, 2) designing and developing an organization that will be able to bring those things towards the goal, 3) assigning certain responsibilities, 4) delegating authority which is necessary for individuals to carry out their duties. Organizing is arrangement of financial, physical, and human resources within the organization. Organizing is the preparation of organizational structure in accordance with the goals of the organization, its resources, and the environment that surrounds it. ${ }^{7}$

The same applies to management of Islamic education, it can succeed and run effectively and efficiently if supported by a solid and good organization. Conversely, if the organization is weak, education will run like a proverb hidup segan mati tak mau (reluctant to live, reluctant to die). Therefore, it can be said that good organizing in the management of education is also the beginning of success for Islamic educational institution.

\section{Scope of Education Management}

Management of education is an effort to explore, nurture, mobilize and maintain educational resources in a balanced and sustainable way to achieve goals through a system of cooperation. The fields include: 8

\footnotetext{
${ }^{6}$ Nanang Fattah, Landasan Manajemen Pendidikan (Bandung: PT. Remaja Rosdakarya, 2004). 71.

${ }^{7}$ Husaini Usman, Manajemen Pendidikan: Teori, Praktik Dan Riset Pendidikan, 2nd ed. (Jakarta: Bumi Aksara, 2008). 141.

${ }^{8}$ Management of education is regulated in Government Regulations No 19 Year 2005, No.19 Year 2007 and No. 17 Year 2010.
} 
- Inventory of educational resources.

- Program of the management of cooperation system in each field through:

- Management of curriculum.

- Management of students.

- Manpower management.

- Financial management.

- Infrastructure management.

- Management of community potentials.

- Management of SKprogram.

- Management of school administration.

- Management of counseling.

- Laboratory management.

- Library management.

- Research report management.

- Skill management.

\section{Implementation of The Government Regulation No.19 Year $2007^{9}$}

The content of Government Regulation No. 19 Year 2005, that the standard of education management is confirmed by some regulations, one of which is Government Regulation No.17 Year 2010 on Management and Implementation of Education. This code regulates the management of education, while in Regulation of National Education Minister No.19 Year2007, it only regulates management ofthe elementary and secondary education. Therefore, this regulation does not remove the previous regulation, but further reinforces the implementation of the rules that have been previously established.

Regulation of National Education Minister No. 19 Year 2007 is an elaboration of the implementation of Government Regulation No. 19 of 2005 on National Education Standard, especially related to the standard of education management that

${ }^{9}$ Ibid. 
should be implemented by the elementary and secondary education units in the jurisdiction of Republic Indonesia.

If seen at educational units existing today, there is still lack of human resources (HR) expected to describe National Education Minister Regulation No. 19 Year 2007. For example, if viewed from the aspect of curriculum, application of KTSP was hindered by the lack of qualified teachers and madrasahs, and supporting infrastructure. Most teachers cannot be expected to contribute creative ideas to elaborate the curriculum guide (KTSP), either on paper or in front of the classroom. One of the causes is the lack of academic qualifications of educators and teachers.

Based on the evaluation conducted by the Department of Research and Development of the Ministry of National Education in 2004 it is reported that the inconsistency of teaching certificate in 2.7 million teachers in the primary and secondary education levels shows a less favorable trend, when referring to the existing requirements. Elementary school teachers who do not have the appropriate diploma are $66.11 \%$, Yunior High School teachers (SMP) are 39.99\%, and Senior High School (SMA) teachers are $34.08 \%$.

In addition, there are $15.21 \%$ of teachers at various levels of primary and secondary education who teach not in accordance with their competence. Theresult of Human Development Index (HDI) survey is that $60 \%$ of elementary school teachers, $40 \%$ of junior high school teachers, $43 \%$ of senior high school teachers, and $34 \%$ of vocational teachers do not meet the national education quality standard. More worrying if $17.2 \%$ of teachers in Indonesia teach not in their expertise. 


\section{Standardization of Managemet of Education}

Based on the policy and implementation of the Regulation of National Education Minister No.19 year 2007, the following policy steps are as follows: ${ }^{10}$

- It is necessary to create an information system that can communicate or monitor the progress of implementation of this regulation in various regions throughout the country.

- Improving the ability and skill of professionals (supervisor, head of madrasah, teacher) so that the regulation can be well implemented.

- Sufficient facilities supporting the implementation of regulation (books, educational tools, and other educational facilities).

- Improving welfare for education implementers to work according to their duties and responsibilities.

- Creating conducive conditions that can make impelementers of education perform their tasks creatively, innovatively, and responsibly.

- Creatin a management of education in accordance with existing legislation and rules, achieving the objectives. It is much better if the human resources in the field are the qualified administrators and managers who have already acquiredorientation course about management of education in accordance with science of administration or management of education.

- Growing community's awareness to participate in improving the quality of learning in madrasah and have a high concern for the condition of madrasah.

${ }^{10} \mathrm{Ibid}$. 


\section{Management of Madrasah Education}

It is argued that with good management, the goal of Islamic education in madrasah will be achieved. Not only that, management becomes very important from all aspects of life. Therefore, management becomes an urgent icon both individually and in group. Scientists vary in defining management even though its essence has the same.

The simplest definition of management is the art of achieving results through various activities done by others. According to John D Millet, management is a process of directing and providing work facilities to people who have been organized in formal groups to achieve the expected goals. James F. Stoner argues that management is the process of planning, organizing, directing and supervising members and other resources to achieve organizational goals that have been established. According to George R. Terry, management is the achievement of a predetermined goal by employing others.

From such definitions, it can be mapped into three things; First, management as a science in which management requires science. Second, management as an art where managers must have management skills.Third, management as a profession, which means that only professional managers who can manage effectively and efficiently.

According to S. Mahmud Al-Hawary, management is knowing where to go, what difficulties to avoid, what forces are being run and how to steer your ship and members as well as possible without wasting time in the process of doing it. ${ }^{11}$

Management has several functions related to goal achievement. Scientists have different opinions about management functions or management elements. According to Louis A. Allen in his book Management and Organization,

\footnotetext{
${ }^{11}$ IPNU, Menajemen Dalam Prespektif Islam (Kraksaan: IPNU, 2008). 1-5.
} 
elements of management consist of planning, organization, motivation, controlling (POCMC). ${ }^{12}$

According to George R. Terry, ${ }^{13}$ elements of management include planning, organizing, actuating, controling (POAC). Meanwhile, according to James A.F. Stoner, management functions include planning, organizing, leading, controlling (POLC). These elements of management will lead to the goals expected by a particular institution or organization.

Management of education in Islam is also inseparable from planning, organizing, coordination, evaluation and motivation. Management in the Islamic context has elements that are not much different from general management concepts. This is available in the Quran and Hadith as the philosophy of Muslim's life. The elements are: First (التخطيط) or planning or description of activities to be implemented using certain methods. As the Prophet Muhammad SAW said,"Indeed Allah loves people who, if do some work, do in itqan (correct, clear and complete). (HR Thabrani)."

In the Quran, Q.S. al-Inshirah (94): 7-8, Allah said,

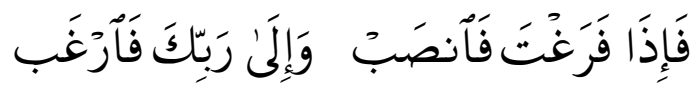

So when you have finished [your duties], then stand up [for worship]. And to your Lord direct [your] longing."

Anything done by man, then he must take responsibility for it. Religion teaches its people to make careful planning and itqan,

\footnotetext{
${ }^{12}$ Louis A. Allen, Management and Organization (Michigan: McGraw-Hill Book Company, 1958).

${ }^{13}$ There are different opinios regarding elements of management from some experts. For instance, George R. Terrysaid that elements of management include planning, organizing, actuating, controlling (POAC). Meanwhile, according to James A.F. Stoner, function of management comprises planning, organizing, leading, controlling (POLC). James A. F. Stoner, Management (Mumbai: Prentice-Hall of India Privated Limited, 2006).
} 
because every work will lead to cause and effect. The existence of good planning will produce good results, and it will be favored by God. Surely the most important assessment is only the judgment that comes from Allah SWT.

Secondly, (التنظي) or organization which reflect everyone's function, and work relationship either vertically or horizontally. In the Q.S. Ali Imran (03): 103, Allah said:

And hold firmly to the rope of Allah all together and do not become divided. And remember the favor of Allah upon you - when you were enemies and He brought your hearts together and you became, by His favor, brothers. And you were on the edge of a pit of the Fire, and He saved you from it. Thus does Allah make clear to you His verses that you may be guided.

This verse shows that the organization is a collection of people who can be well organized. People should be united in working and holding a commitment to achieve the ideals in the umbrella of organization. Allah said in the Q.S. al-Baqarah (2): 286.

Allah does not charge a soul except [with that within] its capacity. It will have [the consequence of] what [good] it has gained, and it will bear [the consequence of] what [evil] it has earned. "Our Lord, do not impose blame upon us if we have forgotten or erred. Our Lord, and lay not upon us a burden like that which You laid upon those before us. Our Lord, and burden us not with that which we have no ability to bear. And pardon us; and forgive us; and have mercy upon us. You are our protector, so give us victory over the disbelieving people.

The same applies to the management of education, if made an analogy that the management of education is shaff(row) that iswell ordered so that the desired goals can be achieved. Therefore, the organization according to this analysis is an association or jama'ahwhich has a regular and orderly system to achieve common goals. In Q.S. al-Șaff (061): 4, Allah said:

Indeed, Allah loves those who fight in His cause in a row as though they are a [single] structure joined firmly. 
The meaning of Șaff, according to al-Qurtubi, is an order to enter in a row (organization) so there is regularity to achieve goals. ${ }^{14}$ In a hadith, the Prophet said:

$$
\text { إن الله عز وجل يحب إذا عمل أحدكم عملا أن يتقنه } 10
$$

Indeed Allah loves people who, if do some work, do in itqan (correct, clear and complete).

If a job is carried out regularly and directedly, the result will be good. Therefore, in a good organization, the process is done in a directed in a correct way (itqān). According to al-Baghawi, the purpose of the above verse is that man should remain in place and not waver from the place. ${ }^{16}$

In addition, some exegetes interpret the verse as a line in the war. ${ }^{17}$ Then the verse indicates the purpose of the war line is trying to carry out the obligations of jihad in the way of Allah and gain victory. In another version of the interpretation, it is argued that the verse shows the sequence in prayer that has regularity. ${ }^{18}$

Work that is done should be tailored to the capabilities of each individual. In putting together such different steps requires patience to organize so that it can be competitive in the work. In addition, Ali bin AbiTalib made the famous statement:

$$
\text { الحق بلا نظام يغلبه الباطل بنظام }
$$

Which means, "Truth that is not organized neatly, can be defeated by iniquity which is well-organized."

\footnotetext{
${ }^{14}$ Ibn 'Abdullāh Muhammad ibn Aḥmad al-Anșārī al-Qurțūbī, "Tafsīr AlQurtūbī,” Vol. I (Kairo: Dār al-Sya'biy, 2005). 5594.

${ }^{15}$ Al-Ṭabrān̄̄, "Mu'jam Al-Ausaț," in Maktabah Shamilah, Vol. 2 (Mauqi'u al-Islam, 2005). 408.

${ }^{16} \mathrm{Abu}$ Muhammad Hasan ibn Mas'ud al-Baghawi, "Mu'alim Al-Tanzīl," in Maktabah Shamilah, Vol. 8 (Dār Ṭayyibah li al-Nashr, 2005). 108.

${ }^{17}$ Ibn Jarir al-Ṭabarī, "Tafsīr Jāmi' Al Bayān Fī Ta'wīl Al-Qur'an," in Maktabah Shamilah, Vol. 23 (Mauqiu Majma’ al-Mulk, 2005). 357.

${ }^{18}$ al-Qurțūbī, "Tafsīr Al-Qurtūbī." 5594.
} 
Ali's statement is a realistic statement to refer for Muslims. The destruction of an institution that occurs today because it does not run the organization with correct management.

Third, (التنسيق) or coordination; that is, the effort to achieve good results ina balanced way, including the steps together to apply the planning to achieve the expected goal, as Allah said in the Q.S. al-Baqarah (02): 208:

O you who have believed, enter into Islam completely [and perfectly] and do not follow the footsteps of Satan. Indeed, he is to you a clear enemy.

If people want to get the title of faith, they must be merged with Islamic rules totally. Faith is like ideal human and Islam is like planning and binding rules for human beings. Hence, to achieve a noble purpose requires good and effective coordination. Constraints are a necessity. However, if humans are immersed in the sea of Islam (peace, cooperation and other good things), they will be released from those obstacles.

Fourth, (الرقابة) or controlling, observation and evaluation of planning. In the view of Islam, leader should be better than his or her members, then the controls will be effective. Allah said in the Q.S. al-Saff (061): 2 and Q.S. al-Tahrim (66): 6.

"O you who have believed, why do you say what you do not do? (Q.S. alShaff [061]: 2)"

"O you who have believed, protect yourselves and your families from a Fire whose fuel is people and stones, over which are [appointed] angels, harsh and severe; they do not disobey Allah in what He commands them but do what they are commanded (Q.S. al-Tahrim [66]: 6)."

Maintaining the safety and success of institution is a primary task of managers. How managers can control others while he is still not controlled. Thus a manager is the best person and must control all his members well. In another verse, Allah explains that the main control is from Allah swt., according to the Q.S. al-Mujādalah (58): 7: 
"Have you not considered that Allah knows what is in the heavens and what is on the earth? There is in no private conversation three but that $\mathrm{He}$ is the fourth of them, nor are there five but that He is the sixth of them - and no less than that and no more except that He is with them [in knowledge] wherever they are. Then He will inform them of what they did, on the Day of Resurrection. Indeed Allah is, of all things, Knowing."

This verse is actually an effective concept of control to apply. Understanding and implementing the context of this verse becomes very urgent. The executors of the institution will carry out their duties consistently in accordance with trust it carries, even they boost their spirit more because they assume that every responsibility is to the Creator (Khaāliq) who knows everything his creatures do.

Fifth, (ترغيب) or motivation; that is, to peform in a maximum way wholeheartedly. Regarding motivation, Allah said in the Q.S. al-Najm (53): 39: "And that there is not for man except that [good] for which he strives"

In another verse, Allah said in the Q.S. al-Ra'dd (13):11:

"For each one are successive [angels] before and behind him who protect him by the decree of Allah. Indeed, Allah will not change the condition of a people until they change what is in themselves. And when Allah intends for a people ill, there is no repelling it. And there is not for them besides Him any patron."

Motivation is an important element in a work activity, because it is a driving force that will create behavior. Motivation is the psychological and mental attitude of humans that provide energy, encourage activities oriented towards reaching the needs and reducing imbalances. The determination of a leader is seen from his motivation, so he looks serious and confident. ${ }^{19}$

Another definition of motivation is given by Stephen P. Khobbins and Marry Coulter, as quoted by Winardi, that

${ }^{19}$ Muchdarsyah Sinungan, Produktivitas Apa Dan Bagaimana (Jakarta: Bumi Aksara, 2003). 134. 
motivation is a willingness to exert efforts in achieving organizational goals conditioned by the ability to meet specific individual needs. ${ }^{20}$

These verses implied the motivation to try and change the situation. The effort to change the situation into a better one will lead to a real goal and success. Allah said (أدعوني أستجب لكم). which means, "Ask forme, I will grant you." In another verse, Allah said in the Q.S. al-Zalzalah (99): 7-8:

"So whoever does an atom's weight of good will see it, And whoever does an atom's weight of evil will see it."

From the above description, it is argued that Islam instructs human beings to have a motivation in life. With high spirit and motivation, someone will achieve a brighter and directed life. Thus, the planning that becomes the main reference will be easily realized, because according to Islam, human motivation is not only to solve worldly demands, but also to take the responsibility to God in the hereafter.

Sixth, (الخلافة) or leading and organizing, leading all activities to the goal. The Quran and Hadith discuss a lot about leadership. Among of them is Q.S. al-An'ām (06): 165:

"And it is He who has made you successors upon the earth and has raised some of you above others in degrees [of rank] that He may try you through what He has given you. Indeed, your Lord is swift in penalty; but indeed, He is Forgiving and Merciful."

In addition to the Qur'an, Hadis discussed a lot about

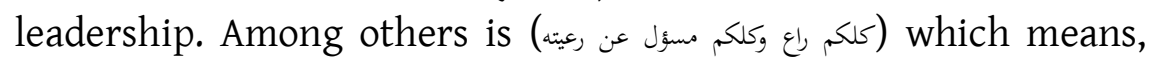
"Every one of you is a leader and every one of you will be accountable for the person you lead" (HR Muslim). In Islam, a leader is not only focused on someone who leads formal and non formal institutions, but leadership is more specific to every human being who lives as a leader, both leading himself and his group. Thus, leadership in Islam starts from each individual.

${ }^{20}$ Winardi, Motivasi Dan Pemotivasian Dalam Manajemen Sumber Daya Manusia. (Jakarta: PT. Raja Grasindo Persada, 2007). 1. 
Everyone should lead himself and get closer (taqarrub) to Allah and know his prohibition. When a man get used to lead himself, it is easier to lead others. Besides, the responsibility of the leader in the Islamic context is not necessarily only to the fellow human beings, but most importantly, the accountability is to God the Creator.

\section{Head of Madrasah as Manager of Education}

In educational units, the head of the madrasah occupies two important positions to ensure the continuity of the educational process as outlined by the legislation. First, the head of madrasah is a manager of education in madrasah. Second, the head of madrasah is the formal leader of education in his madrasah.

As a manager of education, the principal of madrasah is responsible for the success of the implementation of educational activities by implementing administration of madrasah. In addition, the principal of madrasah is responsible for the quality of human resources by enabling them to carry out educational tasks. Therefore, as a manager, the principal of madrasah has a duty to develop the performance of teachers toward professionalism. As a formal leader, the principal of madrasah is responsible for the achievement of educational objectives through mobilization of subordinates toward the achievement of established educational goals.

In this case, the principal of madrasah is in charge of performing the functions of leadership, which is related to the achievement of educational goals and the creation of madrasah conducive atmosphere for the implementation of learning process effectively and efficiently. The effort to empower the personal can be done through proportionate job distribution. In order to make cooperation and tasks to be implemented effectively and efficiently, the madrasah principal's efforts are needed to influence, direct, and control subordinate's behavior toward the attainment of educational goals. Herein lies the 
function of leadership in the implementation of education in madrasah.

According to Achmad Sanusi, ${ }^{21}$ the leadership and management of madrasah demand the head of madrasah to have: (1) the ability and knowledge of the objectives, processes and technologies underlying education at each level of madrasah; (2) the commitment to continuous professional improvement. Furthermore, Moh. Fakry Gaffar (1987: 126) provides guidelines for management of madrasah to create a situation where children can learn better and feel that madrasah is a good place to learn. ${ }^{22}$ To make this goal a reality, a head of madrasah needs to change his orientation by bringing the whole function of Madrasah to one point, that is,educating students. The main tasks of leadership in the context of the principal of madrasah includes: ${ }^{23}$

- Bringing together people of different motivations with the same motivation.

- Making a groupconsciously dynamic.

- Creating an environment where there is integration between individuals and groups and educational institutions.

- Inspiring and encouraging the members to work as effectively as possible.

- Growing awareness of education that always undergoes dynamic changes and keeping the people to adjust to the changing situation.

\section{The Principal of Madrasah as a Leader of Education}

Educational leadership is the ability to influence and mobilize others to achieve educational goals. The function of a

\footnotetext{
${ }^{21}$ Achmad Sanusi, Studi Pengembangan Model Pendidikan Profesional Tenaga Kependidikan (Bandung: IKIP, 1991). 126

${ }^{22}$ Mohammad Fakry Gaffar, Perencanaan Pendidikan: Teori Dan Metodologi (Jakarta: P2LPTK, 1987). 126

${ }^{23} \mathrm{Ibnu}$ Syamsi, Pokok-Pokok Organisasi dan Manajemen (Jakarta: Rineka Cipta, 1994). 138-139.
} 
leader is to facilitate the achievement of organizational goals. Meanwhile, the types of educational leadership include autocratic, paternalistic, charismatic, laissez faire, militaristic, and democratic. The characteristics of good educational leaders are: (1) having the desire to lead, (2) knowledgeable about the ins and outs of the work under his responsibility, (3) mastering and understanding the plan and program; (4) authoritative, (7) creative, (8) having honest, firm, consistent, friendly and humble nature, (6) hard-working, (7) creative, (8) ) full of initiative, (9) diligent and proactive in pursuit of their goals, (10) having a great sense of confidence, (11) flexible in strategy, (12) willing to accept criticism, (13) daring to give his opinion based on common sense , (14) providing an example and role model, (15) being able to cooperate with the people he leads.

Changes in the role and function of madrasah brings wider responsibility to the principal of madrasah, especially to administrators of madrasah. They should have sufficient knowledge of the real needs of the community and the willingness and skills to learn continuously the current changes in the community so that madrasah through its programs can always adapt to new needs and new conditions. ${ }^{24}$

It is suggested that the head of madrasah needs to equip his educational leadership insight with knowledge and anticipative attitude toward changes occurring in community life, including the development of educational policy. The most actual form of change and development today is the increasing community's aspirations towards education, and the incessant demands of educational policy which includes increasing aspects of equal opportunity, quality, efficiency and relevance.

From the point of view of education quality management, educational leadership reflected by the head of madrasah should

\footnotetext{
${ }^{24}$ Sanusi, Studi Pengembangan Model Pendidikan Profesional Tenaga Kependidikan. 117
} 
include a care to improve the quality of education in the educational unit under his leadership. In this connection, the quality of education can be defined as the ability of education to support the learning process to get optimal learning achievement.

This explanation further strengthens madrasah principal's position in determining the success of educational process. In this case, the quality of leadership is highly important because the development of educational activities in each madrasah is determined by the direction, guidance and vision of the head of madrasah.

To be able to carry out his leadership duties properly, the principal of madrasah is required to have competence. This competence should refer to three things as follows: First, personal characteristics of the leader reflected in his attitudes and actions. Second, an ability to perform his duties as a leader which is gained through education and training.Third, rational performance that meet certain specifications in carrying out the task. Robert C. Bog, as quoted by Dirawat, et. Al., ${ }^{25}$ suggests four capabilities that must be possessed by an educational leader.

a. Ability to organize and formulate improved teaching in madrasah in the form of a complete program.

b. Ability to grow and nurture confidence to himself, teachers and other madrasah staffs.

c. Ability to nurture and foster cooperation in proposing and implementing supervisory programs.

d. The ability to encourage and guide teachers and all other madrasah staffs so that they are willing to participate actively in every activities of madrasah to achieve the goals of madrasah.

${ }^{25}$ Dirawat, et al. Pengantar Kepemimpinan Pendidikan (Surabaya: Usaha Nasional, 1983). 88. 
Achmad Sanusi, et. al. ${ }^{26}$ linked the abilities of head of madrasah to his professional mission, which consist of: (1) the ability in administration of madrasah including objective, process and managerial technical capabilities; (2) knowledge on administration of madrasah which includes knowledge relevant to administrative and technical processes; and (3) a commitment to administration of madrasahthat includes an orientation towards improving professional excellence, actively participating in professional teaching and learning activities, and dedication to the development of a complete concept of "the principalshift".

In the pattern of renewal of educational system of teachers in Indonesia, it summarizes the existing competences into three competencies that must be possessed by each professional staff of education:

- Personal competence

An ability that is in line with the national educational foundations and objectives. This competence includes having spirit of Pancasila, piety, virtuous noble character, high-ability in living and reviving the values of Pancasila.

- Professional competence

A technical and administrative ability and solid leadership to implement a quality educational activities.

As an educational leader, the principal of madrasah needs to have the basic competencies derived from Robert L. Katz ${ }^{27}$ such as basic managerial skills:

\footnotetext{
${ }^{26}$ Sanusi, Studi Pengembangan Model Pendidikan Profesional Tenaga Kependidikan. 126 and 436.

${ }^{27}$ T. J. Sergiovanni and Robert J. Start, Supervision, Human Perspective (New York: McGraw-Hill Book, 1979). 25
} 


\section{a. Technical skill}

Skills related to knowledge, methods and certain techniques in accomplishing certain tasks. In practice, the involvement of a leader in any form of "technical skill" is adjusted to the status and level of the leader himself.

b. Human skill

Skills that demonstrate a leader's ability to work effectively with and through others, and to foster cooperation. To achieve this ability, a leader must be able to know himself ("self acceptance") and others. Human skills are highly strategic in order to obtain high organizational productivity, because in the implementation, there is an effort how a leader is able to motivate subordinates.

\section{c. Conceptual skill}

This last skill shows the ability to think, such as analyzing a problem, deciding and solving the problem well. To be able to apply this skill, a leader is required to have a complete understanding of his organization. The goal is that he can act in harmony with the goals of the organization as a whole and on the basis of the goals and needs of his own group.

Human skills is determining a pattern of relationship between the head of madrasah as a leader with the teachers as subordinates. Head of madrasah who is able to use this skill will be able to understand the differences in the maturity of subordinates, which means also understand the level of readiness of each teacher in receiving and carrying out the task to be given.

This is particularly useful for madrasah principals in order to develop the professionalism of each teacher, because an understanding of the level of maturity of subordinates makes the basis for deciding what kind of development activities are most appropriate. The pattern of relationship as above indicates that the head of madrasah cannot believe in one leadership style as a 
fixed price. Therefore, which leadership style is most appropriate for a person (a particular group) is determined by how the level of maturity of a person or group.

Such leadership is called "situational leadership", which according to Hersey and Blanchard, is always based on interrelationship between the following things: (1) the number of instructions and direction given by the leadership, (2) the amount of emotional support given by the leadership, and (3) the level of preparedness or the maturity of followers in performing specific tasks and functions. ${ }^{28}$

\section{Conclusion}

Education is a conscious and well-planned effort to create an atmosphere of learning and learning process so that learners actively develop their potential to have spiritual power, selfcontrol, personality, intelligence, noble character, and skills.

Management is a series of activities that are centred on planning, organizing, mobilization, and supervision in achieving predetermined objectives. Management of education can be defined as the arrangement of activities which relate to educational institutions, all its components, and other institutions.Management of education can also be interpreted as a series of activities such as planning, organizing, motivating, controlling, and developing all efforts to regulate and utilize human resources, facilities and infrastructure to achieve goals education.

In educational units, the principal of madrasahs holds two important positions to ensure the continuity of educational process as outlined by the legislation. First, the head of Madrasah is manager of education in madrasah. Second, the head of Madrasah is the formal leader of education in his madrasah. As a

\footnotetext{
${ }^{28}$ Miftah Thoha, Perilaku Organisasi: Konsep Dasar dan Aplikasinya (Jakarta: Rajawali, 1988). 65-66
} 
manager, principal of madrasah is responsible for the successful implementation of educational activities by implementing school administration. The principal of madrasah is responsible for the quality of human resources in order they carry out educational tasks. Therefore, as a manager, the principal of madrasah has a duty to develop the performance of teachers toward the expected professionalism. As a formal leader, the principal of madrasah is responsible for the achievement of educational objectives through the mobilization of subordinates toward the achievement of established educational goals.

\section{References}

Ahmadi, Abu. Startegi Belajar Mengajar. Bandung: Pustaka Setia, 2005.

al-Baghawi, Abu Muhammad Hasan ibn Mas'ud. "Mu'alim AlTanzīl.” In Maktabah Shamilah, Vol. 8. Dār Ṭayyibah li alNashr, 2005.

Allen, Louis A. Management and Organization. Michigan: McGraw-Hill Book Company, 1958.

Barizi, Ahmad, and Muhammad Idris. Menjadi Guru Unggul. Yogyakarta: Ar-Ruzz Media, 2009.

Dirawat, et al. Pengantar Kepemimpinan Pendidikan. Surabaya: Usaha Nasional, 1983.

Fattah, Nanang. Landasan Manajemen Pendidikan. Bandung: PT. Remaja Rosdakarya, 2004.

Gaffar, Mohammad Fakry. Perencanaan Pendidikan: Teori Dan Metodologi. Jakarta: P2LPTK, 1987.

Ibnu Syamsi. Pokok-Pokok Organisasi dan Manajemen. Jakarta: Rineka Cipta, 1994.

IPNU. Menajemen dalam Prespektif Islam. Kraksaan: IPNU, 2008.

al-Qurțūbī, Ibn 'Abdullāh Muḥammad ibn Aḥmad al-Anșārī. 
“Tafsīr Al-Qurtūbī.” Vol. I. Kairo: Dār al-Sya'biy, 2005.

Republik Indonesia. Undang-Undang Nomor 20 Tahun 2003 Tentang Sistem Pendidikan Nasional. 4th ed. Jakarta: Sinar Grafika, 2011.

Sanusi, Achmad. Studi Pengembangan Model Pendidikan Profesional Tenaga Kependidikan. Bandung: IKIP, 1991.

Sergiovanni, T. J., and Robert J. Start. Supervision, Human Perspective. New York: McGraw-Hill Book, 1979.

Sinungan, Muchdarsyah. Produktivitas Apa dan Bagaimana. Jakarta: Bumi Aksara, 2003.

Stoner, James A. F. Management. Mumbai: Prentice-Hall of India Privated Limited, 2006.

al-Ṭabarī, Ibn Jarir. “Tafsīr Jāmi’ Al Bayān Fī Ta’wīl Al-Qur’an.” In Maktabah Shamilah, Vol. 23. Mauqiu Majma' al-Mulk, 2005.

Al-Ṭabrānī. "Mu’jam Al-Ausaț." In Maktabah Shamilah, Vol. 2. Mauqi'u al-Islam, 2005.

Thoha, Miftah. Perilaku Organisasi: Konsep Dasar Dan Aplikasinya. Jakarta: Rajawali, 1988.

Tilaar, H.A.R. Kekuasaan Dan Pendidikan: Manajemen Pendidikan Nasional dalam Pusaran Kekuasaan. Jakarta: PT Rineka Cipta, 2009.

Usman, Husaini. Manajemen Pendidikan: Teori, Praktik dan Riset Pendidikan. 2nd ed. Jakarta: Bumi Aksara, 2008.

Winardi. Motivasi Dan Pemotivasian dalam Manajemen Sumber Daya Manusia. Jakarta: PT. Raja Grasindo Persada, 2007. 
Vol. 14, No. 1, Juni 2017: 117-139 